\title{
Allozyme Variations to Measure Genetic Diversity in Clonal Accessions of Indian Sandalwood (Santalum album)
}

\author{
Arunkumar A. N. ${ }^{1 *}$ Rekha R. Warrier ${ }^{2}$, A. Shanthi ${ }^{2}$, Geeta Joshi ${ }^{3}$ \\ ${ }^{1,3}$ Institute of Wood Science and Technology, Bengaluru, India \\ ${ }^{2}$ Institute of Forest Genetics and Tree Breeding, Coimbatore, India
}

\begin{abstract}
*Corresponding Author: Arunkumar A. N, Institute of Wood Science and Technology, Bengaluru, India email: anarunkumar@gmail.com
\end{abstract}

\begin{abstract}
Leaf samples of 40 Sandalwood (Santalum album L.) clones assembled at IWST, Bengaluru from natural growing areas and plantations in Tamil Nadu and Karnataka were analysed using horizontal starch gel electrophoresis to study isozyme variability for four enzyme systems: Peroxidase (POD), Aspartate amino transferase (AAT), Glutamate dehydrogenase $(G D H)$ and Malate dehydrogenase $(M D H)$. These systems are reported to show polymorphism in populations of Sandalwood in earlier studies. All the enzymes showed polymorphism in the present study. POD and MDH showing five and four different patterns differentiated the clones. Fourteen bands were scored with an average of 1.2 bands per clone. Presence of isozymes reflects the genetic complexity existing in the clones. No pattern of geographic distribution of isozyme variation was observed. The diversity observed among these clones would be useful in identifying diverse crosscombinations for deriving hybrids and establishing trials for production of seeds.
\end{abstract}

Keywords: Sandalwood clones, diversity, isozymes, variability

Acknowledgements: The authors thank Director, Institute of Wood Science and Technology, for providing necessary help and support during the study. We also thank, Dr. A. Seetharam, Former Project Coordinator (Millets) and Emeritus Scientist, ICAR for constant encouragement.

\section{INTRODUCTION}

Genetic diversity is a prerequisite for long-term survival and adaptability (Young et al., 2000; Bahuguna, 2007).The most serious consequence of its depletion is genetic erosion followed by extinction of species (Kemp et al., 1993). Genetic diversity in Sandalwood is under threat owing to the illegal felling and heavy infestation by spike disease (Arunkumar et al., 2016) and therefore International Union for Conservation of Nature has categorized it as 'Vulnerable'.

Allozymes are a good tool to estimate diversity (Gepts, 1990). They are polymorphic, co-dominant, follow simple inheritance patterns, and occur in plant tissues (Smith, 1989). Progenies from self and cross-pollinations may be differentiated using appropriate isozymes as the electrophoretic pattern obtained is a reflection of the genotype. The biggest advantage of allozyme analysis is that it requires no prior information about the species. The technique could be used directly without modification with any fresh tissue sample of animal, plant, or microbe (Allendorf, 2017).

Preliminary studies on isozyme analysis in Sandalwood were first reported by Parthasarathi et al. (1985) correlating isozyme activity and leaf variations. The authors also reported peroxidase activity in bark tissue as a marker for the oil-bearing capacity (Parthasarathi et al., 1986). Using isozymes, Brand, (1994) estimated genetic variation in Sandalwood plants within and between populations in Timor while Warburton, and (1990) used them to identify provenances in Western Australia. Angadi et al. (2003) reported that provenances of Sandalwood could be delineated using isozymes. Suma and Balasundaran (2003; 2004) assessed the level of genetic variation within and between southern Indian S. album populations using isoenzymes. Rao et al. (2007) analyzed the genetic diversity of 19 Sandalwood populations distributed over different parts of Peninsular India.

Differentiating clones using isozymes has not been reported in Sandalwood. This study, therefore, is an attempt to study diversity in clones of Santalum album to provide preliminary information on their genetic distances. 

album)

\section{MAterials ANd Methods}

Forty accessions of Santalum album (Table 1) from the clonal germplasm bank maintained by the Institute of Wood Science and Technology (IWST), Bangalore were used. These accessions were collected from natural populations/plantations in Karnataka and Tamil Nadu based on their growth and heartwood content. Based on information from literature, only those isozymes reported to reveal polymorphism in Sandalwood were used for the present study.

Table1. Details of 40 clonal accessions used for the study

\begin{tabular}{|c|c|}
\hline Clonal Accession & Origin \\
\hline $\mathrm{K} 1$ & Anekad, Kushal Nagar, Madikeri, Karnataka \\
\hline $\mathrm{K} 2$ & Thindlu, Hoskote, Bangalore, Karnataka \\
\hline K3 & Hulihatti, Ranibennur, Gadag, Karnataka \\
\hline K4 & PWD guest house, Vanivilas Sagar, Chitradurga, Karnataka \\
\hline K5 & IWST, Bangalore, Karnataka \\
\hline K6 & IWST, Bangalore, Karnataka \\
\hline K8 & IWST, Bangalore, Karnataka \\
\hline K9 & IWST, Bangalore, Karnataka \\
\hline K10 & IWST, Bangalore, Karnataka \\
\hline K11 & Hardanhalli, Chamarajnagar, Karnataka \\
\hline K13 & Hardanhalli, Chamarajnagar, Karnataka \\
\hline K14 & Rayalpad (SF, Srinivaspura,) Kolar, Karnataka \\
\hline K16 & Hardanhalli, Chamarajnagar, Karnataka \\
\hline K23 & Honehatti MF, Bhadravathi, Karnataka \\
\hline K27 & Chandrakala, SF, Shikaripura, Sagar, Karnataka \\
\hline $\mathrm{K} 28$ & Ammankatte, Horticultural Farm, Hassan, Karnataka \\
\hline K29 & Muduganur Kaval, Arkalgud, Hassan, Karnataka \\
\hline K31 & Tangali sandal reserve, Kadur, Chickmagalur, Karnataka \\
\hline K35 & Sandal Koti, Kushalangar, Madikeri, Karnataka \\
\hline K37 & Silva Experiment Station, Mudigere, Bangalore, Karnataka \\
\hline $\mathrm{T} 1$ & Sholavaram Research Garden, RR Pudukottai, Tanjavur, Tamil Nadu \\
\hline T3 & Forest Guest House, Anchety, Hosur, Tamil Nadu \\
\hline $\mathrm{T} 4$ & Komateri, Polur, Vellore, Tamil Nadu \\
\hline T5 & Inner Javadhis RF, Alangayam, Thirupathur, Tamil Nadu \\
\hline T6 & Veerapannur RF, Polur, Vellore (1968 plantation), Tamil Nadu \\
\hline $\mathrm{T} 7$ & Veerapannur RF, Polur, Vellore (1970 plantation), Tamil Nadu \\
\hline T8 & Pavanamials Farm, Patta land, Shirkali, Tanjavur, Tamil Nadu \\
\hline T9 & FRC, Kurumbapatty, Shevroys, South Salem, Tamil Nadu \\
\hline T11 & FRC, Kurumbapatty, Shevroys, South Salem, Tamil Nadu \\
\hline T13 & FRC, Kurumbapatty, Shevroys, South Salem, Tamil Nadu \\
\hline $\mathrm{T} 14$ & FRC, Kurumbapatty, Shevroys, South Salem, Tamil Nadu \\
\hline T19 & Mundanthorai, Tirunelveli (1966 plantation), Tamil Nadu \\
\hline $\mathrm{T} 21$ & Mundanthorai, Tirunelveli (1966 plantation), Tamil Nadu \\
\hline T22 & Nachikotai, Harur, Chitteri Dharmpuri, Tamil Nadu \\
\hline T23 & Perieri Village, Pudur East, Chitteri, Harur, Dharmpuri, Tamil Nadu \\
\hline T24 & Thombakal, RF, Shanimadu, Harur, Chitteri, Dharmpuri, Tamil Nadu \\
\hline T26 & Thombakal, RF, Tholthuki Tending Plot, Harur, Chitteri, Dharmpuri, Tamil Nadu \\
\hline T27 & Parigam, Dharmpuri (1974 plantation), Tamil Nadu \\
\hline T28 & Jirgehalli, Hanur, Tamil Nadu \\
\hline T29 & Cattle Farm, Padak - 3 Hosur, Tamil Nadu \\
\hline
\end{tabular}

\subsection{Isozyme Analysis}

Four enzyme systems Peroxidase (POD), Aspartate amino transferase (AAT), Glutamate dehydrogenase $(\mathrm{GDH})$ and Malate dehydrogenase (MDH) were studied (Suma and Balasundaram, 2007). Samples were collected from actively expanding leaves from each of the 40 accessions. About $0.02 \mathrm{~g}$ of these leaves were crushed in $100 \mu \mathrm{l}$ of extraction buffer of $50 \mathrm{mM}$ Tris buffer $(\mathrm{pH} 8.3)$ containing $1 \%$ vitamin $\mathrm{C}(\mathrm{w} / \mathrm{v})$ and $1 \%$ Poly Vinyl Polypyrrolidone (w/v). After centrifugation at $12,500 \mathrm{~g}$ for $30 \mathrm{~min}$, the supernatants were saved as crude extracts. Electrophoresis and staining procedures were adopted from Rovira et al. (1993). After electrophoresis, the gels were incubated in 
staining solutions for a few minutes until clear bands appeared. The gels were washed with distilled water and photographed. The zones were numbered from the slowest to the fastest migration. The relative position of each band was drawn schematically and scored. Scoring was made for those bands which were clearly visible. Genetic interpretation of enzyme phenotypes was based on observed differences in zymogram profile after activity staining of the gel. Variation in banding patterns was determined by the migration from the origin towards the anode.

\subsection{Data Analysis}

POPGENE (Version 1.31) computer program for genetic data analysis was used to analyze allelic data. Standard genetic variability measures were computed for all accessions including the percentage of polymorphic loci $(P)$, the mean observed number of alleles per locus $(n a)$, mean effective number of alleles per locus (ne), the average ( $\left.\mathrm{Avg}_{-} \mathrm{Hets}\right)$, observed $(\mathrm{Ho})$ and expected $(\mathrm{He})$ heterozygosities. The genetic distances obtained were mapped using Treeview 1.6.6 and Darwin 6.0.

\section{RESULTS AND DISCUSSION}

\subsection{Isozyme analysis}

The four enzyme systems provided a total of 14 loci for the 40 Sandalwood accessions. About forty percent (6/14) of the resolved isozyme loci were polymorphic ( 0.99 criterion). Out of these 14 loci, 8 were invariant in all the accessions and were monomorphic. The six alleles observed in MDH-1 MDH-2 AAT-1 GDH-1 POD-1 POD-2 were not equally distributed (Table 2). There were maximum variations in GDH-1 followed by POD-1 locus. Studies have been reported on isozyme variation in $S$. album (Manojkumar et al., 1998), Acacia auriculiformis (Wickneswari and Norwati, 1989), Tectona grandis (Kumaravelu, 1979), Eucalyptus (Aradhya and Phillips, 1993; Martin Corder and Lopes, 1997; Balaji, 1997) and Azadirachta indica (Philomina, 2000).

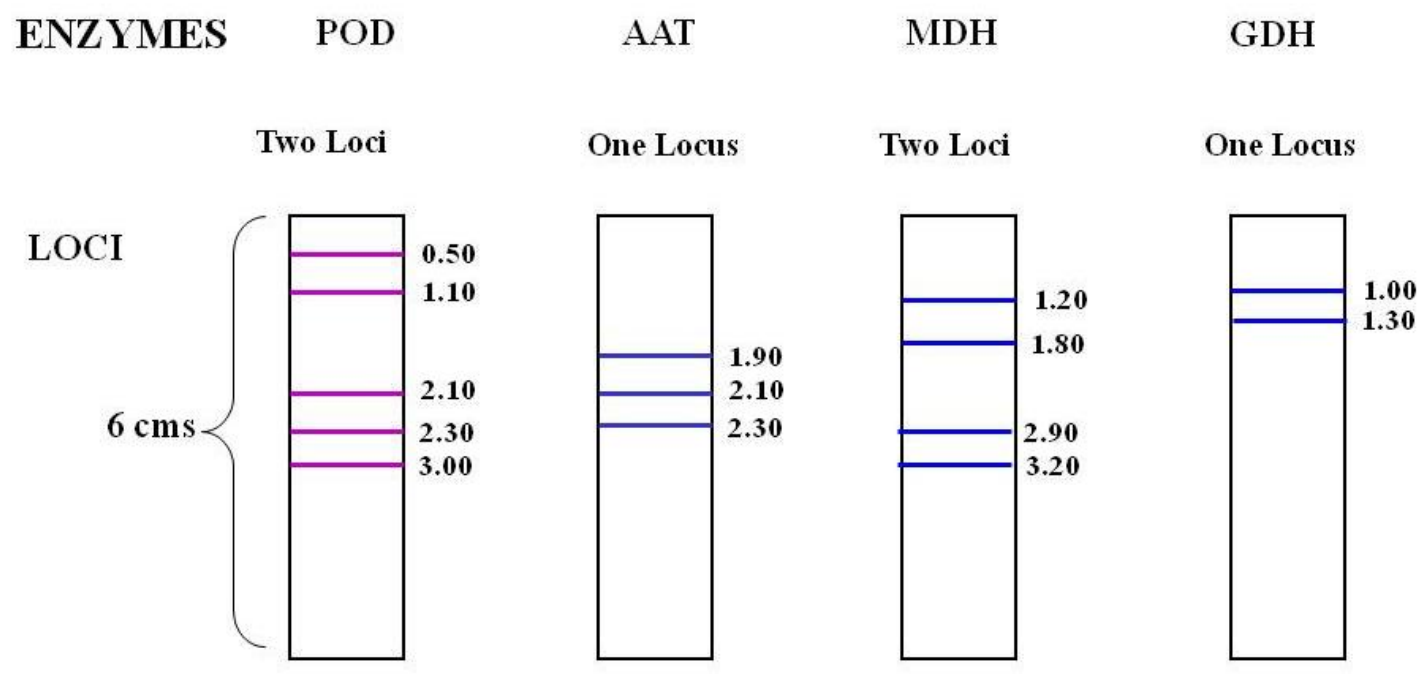

Fig1. Relative mobility $(R f)$ and designation of electrophoretic variants at different loci found in sandalwood accessions

Table2. Summary of heterozygosity statistics for all loci

\begin{tabular}{|c|c|c|c|c|c|}
\hline Marker & $\begin{array}{c}\text { Major Allele } \\
\text { Frequency }\end{array}$ & $\begin{array}{c}\text { Allele } \\
\text { No. }\end{array}$ & $\begin{array}{c}\text { Gene } \\
\text { Diversity }\end{array}$ & $\begin{array}{c}\text { Hetero- } \\
\text { zygosity }\end{array}$ & $\begin{array}{c}\text { Polymorphism information } \\
\text { content }\end{array}$ \\
\hline MDH-1 & 0.80 & 2 & 0.32 & 0.10 & 0.27 \\
\hline MDH-2 & 0.76 & 3 & 0.38 & 0.35 & 0.34 \\
\hline AAT-1 & 1.00 & 1 & 0.09 & 0.07 & 0.09 \\
\hline GDH-1 & 0.41 & 2 & 0.65 & 0.93 & 0.58 \\
\hline POD-1 & 0.61 & 2 & 0.48 & 0.78 & 0.36 \\
\hline POD-2 & 0.81 & 3 & 0.32 & 0.38 & 0.29 \\
\hline
\end{tabular}

The genetic variability measures of the 40 accessions are presented in Table 3 . The mean observed number of alleles per locus was the same as the mean effective number of alleles per locus. The percentage of polymorphic loci $(P)$ ( 0.99 criterion) varied from 0.00 to 46.00 (mean $29.03 \pm 0.02$ ), the 

album)

mean observed heterozygosity ( $\mathrm{Ho}$ ) was $0.21 \pm 0.02$, the mean expected heterozygosity $(\mathrm{He})$ from 0.00 to 0.67 (mean $0.42 \pm 0.02$ ) and gene diversity $(I)$ from 0.00 to 0.33 (mean $0.21 \pm 0.01$ ).

The percentage of polymorphic loci was highest for K5, T7, T26, T27 and T28. The least was observed in K29 followed by K8, T3, T11 and T29. As the accessions were clones, the maximum average number of alleles per locus was also recorded in the clones with highest polymorphism while the minimum numbers of alleles were recorded in accessions exhibiting high homozygosity. Heterozygosity is directly applied as a measure of genetic variation (Crow, 1986). High levels of heterozygosity are important for survival over long life span of trees (Gregorius and Ziehe, 1986), which is related to the low mortality of seedlings and plants (Mejnartowicz and Lewandowski, 1994). Tree species in general are highly out crossing and highly heterozygous as compared to herbaceous perennials and annuals, the average level of heterozygosity being twice that of the herbaceous plants (Hamrick et al., 1979). It was observed that the polymorphic loci ranged between 0 and 46 suggesting that there is a good chance for incorporation of new genes into the next generation. It may be noted that Sandalwood is an entomophillous species and hence a high level of out crossing is normally expected. However, the average heterozygosity was only 21 per cent indicating a lull in gene exchange despite having high polymorphism. The heterozygosity values suggests that if these clones have to be deployed in an orchard for improved seeds, more number of clones need to be included which would probably increase the polymorphic loci, as a result of which the expected heterozygosity and the average heterozygosity would simultaneously increase which is reflected in variation in the heterozygote levels doubling from 0.21 to 0.42 . Reduced number of fertile unrelated trees and a low population size would also result in decreased diversity (Kang and Lindgren, 1998). In the present study, isozyme analyses have provided information about the relative amounts of genetic variation present within Sandalwood accessions distributed in the states of Tamilnadu and Karnataka in India. The genetic variability observed was lower than other plant species summarized by Hamrick et al. (1992). the mean number of alleles per locus per population was 1.42 , which was on par with the average of 1.44 in dicots. The mean expected heterozygosity per population $(0.21)$ in this study was higher than the averages of angiosperm (0.143), out crossing wind-pollinated woody plants $(0.154)$ but equaled tropical tree species (0.217) reported by Martins Corder and Lopes (1997).

Although many woody species maintain relatively high levels of genetic variability (Hamrick and Godt, 1996), some examples exist of widespread conifers with limited genetic variation, such as Pinus resinosa (Fowler and Morris, 1977) and Tsuga canadensis (Zabinski, 1992), with 0 and 10\% polymorphism, respectively. Though geographical range has been considered a good predictor of the levels of genetic variation in plant populations (Hamrick and Godt, 1989), the present study revealed otherwise. Other studies using isozymes have yielded similar results in trees, the rare Pacific yew (Taxus brevifolia) which occurs over a wide range, indicated low polymorphism $(<50 \%)$ (Scher, 1996).

Table3. Percentage of polymorphic loci $(P)$, the mean observed number of alleles per locus (na), mean effective number of alleles per locus (ne), the average (Avg_Het), observed (Ho) and expected (He) heterozygosities, (I) Shannon Weiner index for the forty sandalwood accessions.

\begin{tabular}{|l|l|l|l|l|l|l|}
\hline POP & \multicolumn{1}{|c|}{ Obs_Hom } & Exp_Het* & $\mathbf{I}^{*}$ & na $^{*}$ & ne* $^{*}$ & \%P \\
\hline K1 & 0.67 & 0.33 & 0.17 & 1.33 & 1.33 & 0.23 \\
\hline K2 & 0.67 & 0.33 & 0.17 & 1.33 & 1.33 & 0.23 \\
\hline K3 & 0.50 & 0.50 & 0.25 & 1.50 & 1.50 & 0.35 \\
\hline K4 & 0.50 & 0.50 & 0.25 & 1.50 & 1.50 & 0.35 \\
\hline K5 & 0.33 & 0.67 & 0.33 & 1.67 & 1.67 & 0.46 \\
\hline K6 & 0.50 & 0.50 & 0.25 & 1.50 & 1.50 & 0.35 \\
\hline K8 & 0.83 & 0.17 & 0.08 & 1.17 & 1.17 & 0.12 \\
\hline K9 & 0.67 & 0.33 & 0.17 & 1.33 & 1.33 & 0.23 \\
\hline K10 & 0.50 & 0.50 & 0.25 & 1.50 & 1.50 & 0.35 \\
\hline K11 & 0.50 & 0.50 & 0.25 & 1.50 & 1.50 & 0.35 \\
\hline K13 & 0.67 & 0.33 & 0.17 & 1.33 & 1.33 & 0.23 \\
\hline K14 & 0.67 & 0.33 & 0.17 & 1.33 & 1.33 & 0.23 \\
\hline K16 & 0.50 & 0.50 & 0.25 & 1.50 & 1.50 & 0.35 \\
\hline K23 & 0.50 & 0.50 & 0.25 & 1.50 & 1.50 & 0.35 \\
\hline K27 & 0.50 & 0.50 & 0.25 & 1.50 & 1.50 & 0.35 \\
\hline
\end{tabular}


Allozyme Variations to Measure Genetic Diversity in Clonal Accessions of Indian Sandalwood (Santalum album)

\begin{tabular}{|l|l|l|l|l|l|l|}
\hline K28 & 0.67 & 0.33 & 0.17 & 1.33 & 1.33 & 0.23 \\
\hline K29 & 1.00 & 0.00 & 0.00 & 1.00 & 1.00 & 0.00 \\
\hline K31 & 0.50 & 0.50 & 0.25 & 1.50 & 1.50 & 0.35 \\
\hline K35 & 0.50 & 0.50 & 0.25 & 1.50 & 1.50 & 0.35 \\
\hline K37 & 0.67 & 0.33 & 0.17 & 1.33 & 1.33 & 0.23 \\
\hline 11 & 0.67 & 0.33 & 0.17 & 1.33 & 1.33 & 0.23 \\
\hline T3 & 0.83 & 0.17 & 0.08 & 1.17 & 1.17 & 0.12 \\
\hline T4 & 0.67 & 0.33 & 0.17 & 1.33 & 1.33 & 0.23 \\
\hline T5 & 0.50 & 0.50 & 0.25 & 1.50 & 1.50 & 0.35 \\
\hline T6 & 0.50 & 0.50 & 0.25 & 1.50 & 1.50 & 0.35 \\
\hline T7 & 0.33 & 0.67 & 0.33 & 1.67 & 1.67 & 0.46 \\
\hline T8 & 0.67 & 0.33 & 0.17 & 1.33 & 1.33 & 0.23 \\
\hline T9 & 0.50 & 0.50 & 0.25 & 1.50 & 1.50 & 0.35 \\
\hline T11 & 0.83 & 0.17 & 0.08 & 1.17 & 1.17 & 0.12 \\
\hline T13 & 0.50 & 0.50 & 0.25 & 1.50 & 1.50 & 0.35 \\
\hline T14 & 0.50 & 0.50 & 0.25 & 1.50 & 1.50 & 0.35 \\
\hline T19 & 0.50 & 0.50 & 0.25 & 1.50 & 1.50 & 0.35 \\
\hline T21 & 0.50 & 0.50 & 0.25 & 1.50 & 1.50 & 0.35 \\
\hline T22 & 0.67 & 0.33 & 0.17 & 1.33 & 1.33 & 0.23 \\
\hline T23 & 0.67 & 0.33 & 0.17 & 1.33 & 1.33 & 0.23 \\
\hline T24 & 0.67 & 0.33 & 0.17 & 1.33 & 1.33 & 0.23 \\
\hline T26 & 0.33 & 0.67 & 0.33 & 1.67 & 1.67 & 0.46 \\
\hline T27 & 0.33 & 0.67 & 0.33 & 1.67 & 1.67 & 0.46 \\
\hline T28 & 0.33 & 0.67 & 0.33 & 1.67 & 1.67 & 0.46 \\
\hline T29 & 0.83 & 0.17 & 0.08 & 1.17 & 1.17 & 0.12 \\
\hline
\end{tabular}

na $=$ Observed number of alleles

ne $=$ Effective number of alleles [Kimura and Crow (1964)]

I = Shannon's Information index [Lewontin (1972)]

Expected homozygosty and heterozygosity were computed using Levene (1949)

\subsection{Genetic Diversity}

An enormous amount of protein diversity is characteristic of natural populations (Mallet, 1996). Their genetic structure is mainly influenced by the combined effects of random genetic drift, restricted gene flow and differential selection pressures. These effects lead to low within and comparatively high among population genetic variation in species consisting of small and isolated populations (Holderegger and Schneller, 1994). Generally, when populations are close together, having possibility of enough gene exchange, there should be few differences in gene frequency, but if they are far apart, there should be strong differences (Mallet, 1996). This was partly true in the case of Sandalwood, where accessions were selected from different latitudes. In our study, the genetic identity and distance values calculated between the 40 accessions represented as an UPGMA dendrogram was a fair representation of the Nei's (1972) genetic distances between the accessions, which showed many clusters (Fig. 2).

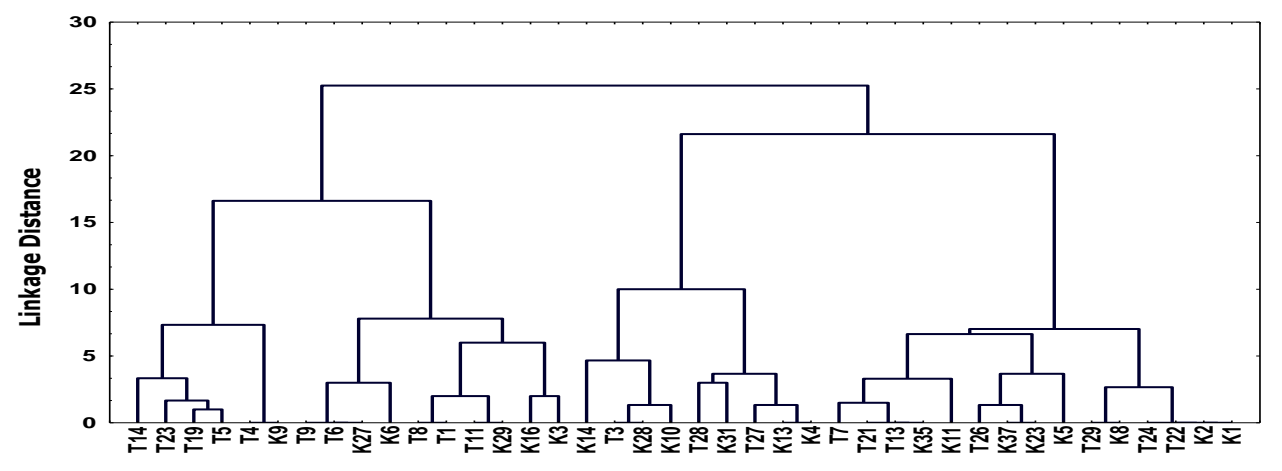

Fig2. Isoenzyme dendrogram (UPGMA) showing clustering of forty sandalwood clones based on Nei's (1972) genetic distance. 
Analysis of genetic relationships revealed heterogeneous values for Nei's genetic identity $(i)$. It ranged from 0.08 (minimum value) to 0.33 (maximum value). All the forty accessions clustered at various levels irrespective of the geographical similarity or distance. Most of the accessions showed similarity. The level of gene flow $(\mathrm{Nm})$ was estimated to be 0.59 (Table 4). F-statistics (Table 4) provided the measure of deviations in gene frequencies from Hardy-Weinberg expectations.

Table4. Summary of F-Statistics and gene flow for all loci

\begin{tabular}{|c|c|c|c|c|c|}
\hline & Fst & Nm* & na* $^{*}$ & ne$^{*}$ & $\mathbf{I}^{*}$ \\
\hline Mean & 0.41 & 0.36 & 2.33 & 1.72 & 0.59 \\
\hline
\end{tabular}

$\mathrm{Nm}=$ Gene flow estimated from Fst $=0.25(1-$ Fst $) /$ Fst.

na $=$ Observed number of alleles

ne $=$ Effective number of alleles [Kimura and Crow (1964)]

I = Shannon's Information index [Lewontin (1972)]

A lack of alliance was observed between genetic data and geographical locations of the populations. Accessions studied from the same localities were grouped into different clusters separated by a fair distance suggesting that they were genetically distinct. Despite this, the genetic variability estimates were low. The accessions would have been brought from different places where they have grown in varied climatic and edaphic conditions, but the base material could have been genetically closer. Rao et al. (2007) reported that total variability in Sandalwood was due to differences among the populations rather than within geographical regions. Sandalwood trees are primarily out crossed and to avoid inbreeding depression they require sufficiently large populations for gene flow to occur. In this study, the clones though showed a $\mathrm{He}$ of 0.21 , could be increased to 0.42 provided the genetic base is further widened which would then improve the gene flow and mating opportunities resulting in improved progenies.

Sandalwood trees in their natural stands have been depleted considerably due to illicit felling, (Rao, 2004), lack of regeneration (Sreenivasan et al. 1992) and spike disease (Radomiljac et al. 1998). This has led to an awareness on the need for conservation of the species both through ex-situ (Sreenivasan et al. 1992) and in-situ measures (Rao, 2004). Priority for genetic conservation has often been set based on the level of genetic diversity and allelic uniqueness of populations as well as on the degree of gene differentiation between populations (Coates and Sokolowski, 1992). A major bottleneck described by various researchers working on Sandalwood, is restricted gene flow and poor mating opportunities (Suma and Balasundaran, 2003; 2004; Rao et al., 2007). The present study, which comprised accessions from predominantly natural Sandalwood growing areas of Karnataka and Tamilanadu, showed that most alleles were shared. Therefore, conserving a single large and genetically diverse population may help capture most of the variation. Thus, in addition to identification of 'hot-spots' of genetic variability, the concept of a National Germplasm Bank for Sandalwood would enable not only conservation planning but also for collecting and maintaining diverse genetic material for Sandalwood tree improvement. With the demand for Sandalwood constantly on the rise, a consolidated approach as suggested here will help in its conservation and efficient utilisation.

\section{REFERENCES}

[1] Allendorf, F. W. (2017), Genetics and the conservation of natural populations: allozymes to genomes. Molecular Ecology, 26: 420-430.

[2] Angadi, V. G., Jain, S. H. and Shankaranarayana, K. H. (2003). Genetic diversity between sandal populations of different provenances in India. Sandalwood Research Newsletter, 18: 45.

[3] Aradhya, K. M. and Phillips, V. D. (1993). Genetic variability in elite Eucalyptus provenances and progenies selected for arid environments in Hawaii. Silvae Genetica, 45(2): 145-150.

[4] Arunkumar, A. N., Joshi, G., Rao, M. S., Rathore, T. S. and Ramakantha, V. (2016). The population decline of Indian sandalwood and people's role in conservation - an analysis. In: Nautiyal S., Schaldach R., Raju K.V, Kaechele H., Pritchard B., Rao K.S. (eds) Climate Change Challenge (3C) and SocialEconomic, Ecological Interface-Building. Springer International Publishing, Switzerland, pp. 377-387. 
[5] Balaji, B. (1997). Multivariate analysis and interspecific hybridization in Eucalyptus species. M.Sc. (For.) Thesis, Forest College and Research Institute, TNAU, Coimbatore, India.

[6] Bahuguna, A. (2007). Conservation genetics: A management tool. Annals of Forestry, 15: 159-200.

[7] Brand, J. E. (1994). Genotypic variation in Santalum album. Sandalwood Research Newsletter, 2: 24.

[8] Coates, D. J. and Sokolowski, R. E. S. (1992). The mating system and patterns of genetic variation in Bankia cuneta A. S. George (Proteaceae). Heredity, 69: 11-20.

[9] Crow, J. F. (1986). Basic concepts in population, quantitative, and evolutionary genetics. W. H. Freeman \& Comp., New York.

[10] Fowler D. P. and Morris, R.W. (1977). Genetic diversity in red pine: evidence for low genetic heterozygosity. Canadian Journal of Forest Research, 7: 343-347.

[11] Gepts, P. (1990). Genetic diversity of seed storage proteins in plants. In: A. Brown, M. Clegg, A. Kahler and B. Weir (Eds.) Plant Population Genetics, Breeding and Genetics Resources. Sinaver, Sunderland, MA, USA, pp. 64-82.

[12] Gregorius, H. R. and Ziehe. M. (1986). The significance of over- and underdominance for maintenance of genetic polymorphism. II. Overdominance and instability with random mating. Journal of Theoretical Biology, 118: 115-125.

[13] Hamrick, J. K. and Godt, M. J. W. (1989). Allozyme diversity in plant species. In: A. H. D. Brown, M. T. Clegg, A. L. Kahler and B. S. Weir (Eds.) Plant population genetics, breeding and genetic resources. Sinauer Associates, Sunderland, Massachusetts, pp. 43-63.

[14] Hamrick, J. L., Godt, M. J. W. and Sherman-Broyles, S. L. (1992). Factors influencing levels of genetic diversity in woody plant species. New Forests, 6: 95-124.

[15] Hamrick, J. L., Linhart, Y. B. and Mitton, J. B. (1979). Relationships between life history characteristics and electrophoretically detected genetic variation in plants. Ann. Rev. Ecol. Syst., 10: 173-200.

[16] Hamrick, J.L. and Godt, M.J.W. (1996). Effects of life history traits on genetic diversity in plant species. Philosophical Transactions of Royal Society of London, B, 351:1291-1298.

[17] Holderegger, R. and Schneller, J. J. (1994). Are small isolated populations of Asplenium septentrionale variable? Biological Journal of the Linnean Society, 51:377-385.

[18] Kang, K.S. and Lindgren, D. (1998). Fertility variation and its effect on the relatedness of seeds in Pinus densiflora, Pinus thunbergii and Pinus koraiensis clonal seed orchards, Silvae Genetica, 47(4): 196-201.

[19] Kemp, R. H., Namkoong, G. and Wadsworth, F. H. (1993). The nature of forest genetic resources. In: Conservation of genetic resources in tropical forest management principles and concepts. FAO Forestry paper 107. Rome, pp. 514.

[20] Kimura, M. and Crow, J.F. (1962). The number of alleles that can be maintained in a finite population, Genetics 49: 725-738.

[21] Kumaravelu, G. (1979). Isozyme characterization of teak clones. Indian Forester, 105: 716-719

[22] Levene, H. (1949). On a matching problem arising in genetics. The Annals of Mathematical Statistics, 20:91-94.

[23] Lewontin, R. C. (1972). The apportionment of human diversity. Evolutionary Biology, 6: 381-398.

[24] Mallet, J. (1996). The genetics of biological diversity from variety to species. In: K.J. Gaston (Ed.) Biodiversity-A biology of numbers and differences. Blackwell Science, UK, pp.13-53.

[25] Manojkumar M. R., Subramanian, S. and Kumaravelu, G. (1998). Isozyme studies in clonal bank of sandal (Santalum album L.). In: Advances in Forestry Research in India, Volume XVIII. 267p.

[26] Martins-Corder, M. P. and Lopes, C. R. (1997). Isozyme characterization of Eucalyptus urophylla (S. T. Blake) and E. grandis (Hill ex Maiden) populations in Brazil. Silvae Genetica, 46(4): 192-197.

[27] Mejnartowicz, L. and Lewandowski, A. (1994). Allozyme polymorphism in seeds collected from IUFRO68 Douglas-fir test-plantation. Silvae Genetica, 43: 181-186.

[28] Nei, M. (1972). Genetic distance between populations. American Naturalist, 106: 283-292.

[29] Parthasarathi, K., Angadi, V. G., Sankaranarayana, K. H. and Rajeevalochan, A. N. (1986). Peroxidase isozyme activity in living barks tissue as a marker for oil bearing capacity in sandal. Current Science, 55: 831-834.

[30] Parthasarathi, K., Rangaswamy, C. R. and Angadi, V.G. (1985). Leaf peroxidase, malate dehydrogenase and esterase isoenzyme pattern in ten sandal (Santalum album L.) types showing variation in leaf pattern. Indian Forester, 111: 441-449.

[31] Philomina, D. (2000). Genetic analysis of one-parent families for variability, diversity, stability and propagation techniques in neem (Azadirachta indica A. Juss.) Ph.D. Thesis, TNAU, Coimbatore, India, $246 \mathrm{p}$. 
[32] Radomiljac, A., McComb, J. A., Pate, J. S. and Tennakoon, K. U. (1998). Xylem transfer of organic solutes in Santalum album L. (Indian sandalwood) in association with legume and non-legume hosts. Annals of Botany, 82: 675- 682.

[33] Rao, M. N. (2004). Mapping genetic diversity of Sandal (Santalum album L.) genetic resources in peninsular India using biochemical and molecular markers: Lessons for in-situ conservation. PhD thesis, Forest Research Institute (FRI), ICFRE, Dehra Dun, India.

[34] Rao M. N., Ganeshaiah K.N. and Uma Shaanker, R. (2007). Assessing threats and mapping sandal resources to identify genetic hot spots for in situ conservation in peninsular India. Conservation Genetics, 8: 925-935.

[35] Rovira, M., Aletà, N., Germain, E. and Arús, P. (1993). Inheritance and linkage relationships of ten isozyme genes in hazelnut. Theoretical and Applied Genetics, 2-3(86): 322-328.

[36] Scher, S. (1996). Genetic structure of natural Taxus populations in western North America. In: T.B., Smith and R.K., Wayne (Eds.) Molecular Genetic Approaches in Conservation, pp. 424-441. Oxford University Press, New York.

[37] Smith, J. S. C. 1989. The characterization and assessment of genetic diversity among maize (Zea mays L.) hybrids that are widely grown in France: Chromatographic data and isozymic data. Euphytica, 43(1):7385 .

[38] Srinivasan V. V., Shivaramakrishnana, V. R., Rangaswamy, C R., Ananthapadmanabha, H. S. and Shankaranarayana, K.H. (1992). Sandal. Dehradun: Indian Council of Forestry Research and Education.

[39] Suma, T. B. and Balasundaran, M. (2003). Isozyme variation in five provenances of Santalum album in India. Australian Journal of Botany, 51:243- 249

[40] Suma, T. B. and Balasundaran, M. (2004). Genetic diversity of eight Santalum album provenances of India based on RAPD analysis. Indian Journal of Genetics and Plant Breeding, 64:167-168.

[41] Suma, T. B. and Balasundaran, M. (2007). Variation in genetic diversity and seedling survival of sandal provenances. In: (Eds. S. Gairola, T. S. Rathore, G. Joshi, A. N. Arun Kumar, and P. Aggarwal.) Proceedings of the National Seminar on Conservation, Improvement, Cultivation and Management of Sandal (Santalum album L.), 12-13 December, 2007. Institute of Wood Science and Technology, Bangalore. pp. 40-46.

[42] Warburton, M. L. and Bliss, F. A. (1996). Genetic diversity in peach (Prunus persica L. Batch) revealed by randomly amplified polymorphic DNA (RAPD) markers and compared to inbred coefficients. Journal of American Society of Horticultural Science, 121: 1012-1019.

[43] Wickneswari, R. and Norwati, M. (1993). Genetic diversity of natural populations of Acacia auriculiformis. Australian Journal of Botany, 41: 65-77.

[44] Yeh, F. C. and Boyle, T. J. B. (1997). Population genetic analysis of co-dominant and dominant markers and quantitative traits. Belgian Journal of Botany, 129:157-163.

[45] Young, A., Boshier, D. and Boyle, T. (2000). Forest Conservation Genetics: Principles and Practice. Edited by A. Young, D. Boshier and T. Boyle. CSIRO Publishing, Collingwood VIC, Australia. pp. 13

[46] Zabinski, C. (1992). Isozyme variation in eastern hemlock. Canadian Journal of Forest Research, 22:1838-1842.

Citation: A. N. Arunkumar et al., "Allozyme Variations to Measure Genetic Diversity in Clonal Accessions of Indian Sandalwood (Santalum Album)", International Journal of Forestry and Horticulture, vol. 4, no. 1, p. 1 8, 2018. http://dx.doi.org/10.20431/2454-9487.0401001

Copyright: (C) 2018 Authors. This is an open-access article distributed under the terms of the Creative Commons Attribution License, which permits unrestricted use, distribution, and reproduction in any medium, provided the original author and source are credited. 